DOI https://doi.org/10.32841/2409-1154.2020.44.45

\author{
Vlasenko L. V., \\ Senior Teacher of Department of Foreign Philology and Translation \\ Kyiv National University of Trade and Economics
}

\author{
Trygub I. P., \\ Senior Teacher of Department of Foreign Philology and Translation \\ Kyiv National University of Trade and Economics
}

\title{
FOREIGN LANGUAGE COMPETENCE OF FUTURE ECONOMISTS
}

\begin{abstract}
Summary. The development of foreign language professional and communicative competence is the necessary component of the professional training of economic universities' students and the urgent condition for the formation of professional who is capable to communicate with specialists from other countries in the multicultural space in conditions of international mobility.

Creating conditions for the competitive advantage in the world is the main condition for the economic and social stability in Ukraine. Expected changes are possible only if the increase in labor productivity, which depends on the presence of highly qualified specialists in the domestic labor market today. Consequently, any transformations in the economy are impossible without educational reforms and modernization of training competitive professionals.

The ability to compete at the labour market in the globalized environment is increasingly connected with various competencies of the specialist, so the competencybased approach of forming a competitive professional is extended to the language training of graduates. The Council of Europe has identified the list of five key competences to teach young Europeans in terms of expanding and integrating labour markets, increasing migration, unemployment and, as a consequence, increasing social inequality.
\end{abstract}

For the development of foreign language competence, students must be practiced involved in all foreign language skills, but for students who are going to work in the international companies, it is important to have the monologue and dialogue skills too. For students of economics, for example, the important aspect is an ability to give the presentation, to run the meeting and to participate in the negotiation. Important prerequisite is to have listening skills, namely to hear the content of oral utterances in the foreign language on professional subject.

Thus, to master language is not only to understand and know, it is to have an ability to mobilize acquired language skills to solve certain communicative problems in different contexts, situations, areas of educational, scientific and professional activity. In addition, not every knowledge is logically transformed into the skill, but the latter is usually formed through knowledge.

Key words: competence, communicative competence, professional, foreign language, competitive specialist.

Urgency of the research. Integration of Ukraine into the European space and the economic aspect of globalisation influence specialists from various fields. Foreign language competence enables young people to find employment in various international organisations and companies, to participate in international projects, to study in international educational establishments, and to increase the competitiveness of professionals in the labour market.

Problem of the article. The feature of the teaching foreign language process to university students is the lack of the vital foreign language environment. It is known that some people, getting into the particular country, quickly master the skills of speaking foreign language and communicate with native speakers, without knowing its grammar. The linguistic norms of foreign speech are assimilated by them not in the form of conscious rules of the language, but purely intuitively, that is, the person learns to use foreign language, not knowing the rules, but only feeling them on practice. If there is a vital need for the language is studied in the conditions of a complete foreign language environment, people master the necessary minimum of foreign words and phrases that allow them to communicate with native speakers and solve their everyday and business issues.

Results and discussions. The problem of the formation of professional language competence has been investigated by many researchers, such as O. Bigich, I. Zadorozhna, S. Kozak, N. Mykytenko, L. Morska, O. Moskalenko, S. Nikolaieva, O. Tarnopolskyi, L. Chernovatyi, Ye. Komarova, T. Kuskova, N. Kucherenko, T. Lopatukhina, T. Luchkina, Yu. Maslova, R. Milrud, A. Samsonova, O. Fadeikina, L. Fishkova, L. Haliapina, I. Tsaturova, M. Shyshota and others.

The purpose of the article. The aims are: is to consider the concept of foreign language competence in terms of students' linguistic activity, to analyse the development of speech competence as the necessary component in the structure of competencies to improve the quality of competitive professionals' training.

Materials and methods. Foreign language communicative competence is considered as the set of three competencies: linguistic, speech and socio-cultural competencies.

For some students, their goal is communication in business. For others, their goal is to communicate during their advanced studies at an English-language university or college. Still others want to explore the world and will use English to travel and communicate with people all over the globe.

Linguistic competence should be understood as the linguistic knowledge of the individual and its ability to process them. Linguistic competence includes linguistic knowledge (lexical, grammatical), language skills (phonetic and spelling) and relevant socio-cultural knowledge (country and linguistic studies). The speech competence implies the ability to form and express the opinion through linguistic means, the ability to perceive and formulate the speech in the foreign language. The speech competence includes four 
types of communication: listening, speaking, reading and writing. The competence in speaking is the competence in dialogical and monologue speech.

The speech competence, in our opinion, is knowledge of the rules of linguistic behavior, the choice of language forms and means, their use according to the communicative situation of participants in the process of professional communication.

The ability to compete at the labour market in the globalized environment is increasingly connected with various competencies of the specialist, so the competency-based approach of forming a competitive professional is extended to the language training of graduates. The Council of Europe has identified the list of five key competences to teach young Europeans in terms of expanding and integrating labour markets, increasing migration, unemployment and, as a consequence, increasing social inequality.

1. Political and social competences.

2. Competences related to life in the multicultural society.

3. Competences related to speaking and writing.

4. Competences related to the development of the information society.

5. Willingness and ability to learn throughout the life.

Competence is a common ability based on knowledge, experience, values, abilities and knowledge gained through learning.

Domestic researchers view the foreign language competence as the result of efforts taken to develop foreign-language knowledge and skills that reflect the professional contextual, psychological, social and situational status of the language as a means of professional communication in the field of finance and personal communication.

E. Bibikova under the term "the foreign language communicative competence means the ability and willingness of the subject of professional activity to engage the foreign language in professional communication" [1].

$\mathrm{N}$. Sura in the foreign language competence means possessing a specialist with the necessary amount of knowledge, skills that determines the degree of formation of student's professional activity, the style of professional communication and his/ her personality as the bearer of certain values, ideas and professional consciousness [5].

Another approach was offered by Yu. Solodovnikova, who states that the communicative competence in the foreign language is a complex personal resource that provides an opportunity for effective interaction in the field of social work, the process of foreign language using as the means of solving professional problems of social work. In this case, Yu. Solodovnikova distinguishes in the structure of professional training of the future specialist two separate components the foreign language communicative competence and the general professional competence [4].

A. Pavlenko defines the communicative activity as language learning, the level of practical knowledge of both verbal and non-verbal means, means of communicative management, tools of Internet technologies, and also experience the language proficiency at the variably-adapted level depending on a special speech situation [3, p. 430].

Many foreign and domestic scholars (V. Safonov, N. Borysko) point out that students do not develop abilities to participate in foreign language intercultural communication when learning foreign language outside the country where they speak the language, automatically, only through the presentation of foreign language and culture.
The success in intercultural communication depends, according to O. Tarnopolskyi, L. Dimova and N. Borysko, on several conditions:

1) students' psychological readiness for intercultural communication;

2) possession of communicators, a common "repertoire", which is formed by linguistic, social and cultural content aspects of three levels' communication: universal, national and personalityspecific [2, p. 225].

For the formation of foreign language vocationally oriented communication competence, it is necessary to ensure the practical orientation of learning foreign language.

In our opinion, in the process of learning foreign language students of non-language educational institutions should know:

1) the structure of the language they are learning (phonetics, vocabulary, grammar);

2) the specifics of scientific literature that could be used in the professional field;

3) rules for composing annotations, abstracts, reports, presentations (when writing Master's Degree thesis);

4) rules for writing summary, business correspondence, etc.

The importance of motivation in teaching and learning process makes teacher is aware that one of the roles that must be done in teaching process is as a motivator for students. Every teacher has a different way in motivating students; even what teachers done in teaching and learning process, it could be the form of motivational strategies.

The teacher plays an important role in motivating student especially in the foreign language classroom [6, p. 14]. The development of classroom engagement increases when the teacher has the ability to build students motivation in teaching and learning process. Ramirez [7, p. 22] states "the teachers" ability to motivate is important because it creates a free stressed atmosphere and establishes a relationship of mutual confidence and motivation". From that statement, it is clear that a teacher should have ability to make a positive atmosphere and good relation with students in classroom, because when all of classroom elements can support each other, it will build students motivation to learn confidently.

However, for the development of foreign language competence, students must be practiced involved in all foreign language skills, but for students who are going to work in the international companies, it is important to have the monologue and dialogue skills too. For students of economics, for example, the important aspect is an ability to give the presentation, to run the meeting and to participate in the negotiation. Important prerequisite is to have listening skills, namely to hear the content of oral utterances in the foreign language on professional subject.

Conclusions. Thus, to master language is not only to understand and know, it is to have an ability to mobilize acquired language skills to solve certain communicative problems in different contexts, situations, areas of educational, scientific and professional activity. In addition, not every knowledge is logically transformed into the skill, but the latter is usually formed through knowledge.

Consequently, language proficiency is the multicomponent, complex concept that implies both the individual richness of the speaker's vocabulary and the clarity, accuracy, expressiveness, normativity of his/ her speech, and understanding the nuances 
of the words meaning, and distinguishing linguistic means by their stylistic coloring, and perfect mastery of the ways of constructing texts and sentences of different structure by means of this language, and knowledge of national peculiarities of form and word formation and speech etiquette, as well as the ability to provide phonetics and intonation severity of their spoken language.

The speech competence is the combination of thinking and language, the precision of expression of thoughts, feelings, clarity, the comprehensibility of semantic connections and the relations of the speech units in communication and the relation of objects and phenomena in reality. Culture of speaking, as well as communication culture, must be taught at all stages of training and retraining of the competitive professionals.

\section{References:}

1. Бибикова Е.В. Формирование основ иноязычной коммуникативной компетентности у будущих экологов : автор. дис. ... канд. пед. наук : 13.00.08. Майкоп, 2006. 29 с.

2. Бориско Н.Ф. Теоретичні основи створення навчально-методичних комплексів для мовної міжкультурної підготовки вчителів іноземних мов (на матеріалі інтенсивного навчання німецької мови) : дис. докт. педагог. наук : 13.00 .02 / Київськ. держ. лінгв. -т. Київ, 2000. 508 с.

3. Павленко О.О. Формування комунікативної компетенції фахівців митної служби в системі неперервної освіти : дис. докт. педагог. наук : 13.00.04. $560 \mathrm{c}$.

4. Солодовникова Ю.Ю. Формирование иноязычной коммуникативной компетенции как условие совершенствования профессиональной подготовки специалиста социальной работы : автореф. дис. на соискание степени канд. пед. наук : спец. 13.00.08 «Теория и методика профессионального образования» / Ю.Ю. Солодовникова. Курск, 2009. 28 с.

5. Сура Н.А. Навчання студентів університету професійно-орієнтовного спілкування іноземною мовою : автореф. дис. ... канд. пед. наук : 13.00.04. Луганськ, 2005. 20 c.

6. Astuti, S. P. (2013). Teacher's and student's perception of motivational teaching strategies. TEFLIN Journal, 24 (2), 14-31. Retrieved from http://www.journal.teflin.org

7. Ramirez, A.C.V. (2010). Students' perception about the development of their oral skills in an English as foreign language teacher training program. Retrieved from http://www.researcharchive.edu.tw.
Власенко Л. В., Тригуб І. П. Іншомовна компетентність під час вивчення іноземних мов майбутніми економістами

Анотація. Розвиток іншомовної професійної та комунікативної компетентності є необхідним складником професійної підготовки студентів економічних університетів та нагальною умовою формування професіонала, здатного спілкуватися з фахівцями інших країн у полікультурному просторі в умовах міжнародної мобільності.

Створення умов для конкурентної переваги у світі $\epsilon$ головною умовою економічної та соціальної стабільності в Україні. Очікувані зміни можливі лише за умови підвищення продуктивності праці, що залежить від присутності на вітчизняному ринку праці висококваліфікованих фахівців. Отже, будь-які трансформації в економіці неможливі без освітніх реформ та модернізації підготовки конкурентоспроможних професіоналів.

Здатність конкурувати на ринку праці в глобалізованому середовищі все більше пов'язана з різними компетенціями фахівця, тому компетентнісний підхід формування конкурентоспроможного професіонала поширюється на мовну підготовку випускників. Рада Європи визначила перелік ключових компетенцій щодо навчання молодих європейців та щодо розширення та інтеграції ринків праці, збільшення міграції, безробіття та, як наслідок, збільшення соціальної нерівності.

Для розвитку компетентності з іноземної мови студентів потрібно практикувати, беручи участь у всіх навичках з іноземної мови, але для студентів, які збираються працювати в міжнародних компаніях, важливо також мати навички монологічного та діалогічного мовлення. Наприклад, для студентів економічних спеціальностей важливим аспектом $є$ вміння проводити презентацію, зустрічі та брати участь у переговоpax. Важливою умовою є вміння слухати, а саме слухати зміст усних висловлювань іноземною мовою на професійну тему.

Таким чином, оволодіння мовою - це не лише розуміння та знання, це вміння мобілізувати набуті мовні навички для вирішення певних комунікативних проблем у різних контекстах, ситуаціях, сферах навчальної, наукової та професійної діяльності. Крім того, не кожне знання логічно перетворюється на майстерність, яка своєю чергою зазвичай формується через знання.

Ключові слова: компетенція, комунікативна компетенція, професіонал, іноземна мова, конкурентоспроможний спеціаліст. 